Canadian Journal of Bioethics

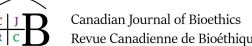

Revue canadienne de bioéthique

\title{
Launch of the Canadian Journal of Bioethics
}

Lancement de la Revue canadienne de bioéthique

\section{Bryn Williams-Jones, Charles Dupras, Vincent Couture and Renaud Boulanger}

Volume 1, Number 1, 2018

Ethics and International Development Research

Éthique et recherche en développement international

URI: https://id.erudit.org/iderudit/1058305ar

DOI: https://doi.org/10.7202/1058305ar

See table of contents

Publisher(s)

Programmes de bioéthique, École de santé publique de l'Université de Montréal

ISSN

2561-4665 (digital)

Explore this journal

Cite this document

Williams-Jones, B., Dupras, C., Couture, V. \& Boulanger, R. (2018). Launch of the Canadian Journal of Bioethics. Canadian Journal of Bioethics / Revue canadienne de bioéthique, 1(1), 1-3. https://doi.org/10.7202/1058305ar

All Rights Reserved @ Bryn Williams-Jones, Charles Dupras, Vincent Couture, Renaud Boulanger, 2018

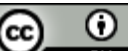

This document is protected by copyright law. Use of the services of Érudit (including reproduction) is subject to its terms and conditions, which can be viewed online.

https://apropos.erudit.org/en/users/policy-on-use/ 
ÉDITORIAL / EDITORIAL

\title{
Launch of the Canadian Journal of Bioethics
}

\author{
Bryn Williams-Jones ${ }^{1}$, Charles Dupras ${ }^{2}$, Vincent Couture ${ }^{2}$, Renaud Boulanger ${ }^{2}$
}

After six years (2012-2017) of publishing innovative bioethics scholarship, BioéthiqueOnline becomes the Canadian Journal of Bioethics/Revue canadienne de bioéthique (cib-rcb.ca). As executive editors of BioéthiqueOnline, we frequently heard from members of the Canadian bioethics community of the need to develop a platform with the right branding to showcase the value and the richness of our collective reflections, both locally and internationally. Following discussions with colleagues across the country, we came to the conclusion that BioéthiqueOnline had developed a unique expertise publishing bioethics scholarship, but that the original name, created to convey the bilingual and open access mission of the journal, was not enthusiastically received. So the time has come to upgrade and rebrand as the Canadian Journal of Bioethics (CJB).

The journal's mission remains unchanged: it will continue to provide a bilingual (French and English) space for diverse forms of high quality and thought-provoking scholarship (e.g., peer-reviewed articles and commentaries, reviews, editorials, case studies, creative works) from across the full range of bioethics specialties (e.g., clinical ethics, research ethics, public health ethics, technology ethics, professional ethics). The journal maintains its philosophy of publishing fully open access - that is, free from author publication charges or access fees. For those who grew accustomed to relying on BioéthiqueOnline for updates on bioethics related news, events, and job opportunities, rest assured that this resource will remain! BioéthiqueOnline will now be the social media arm of the journal (Twitter, Facebook, Linkedln), and share relevant information about Canadian bioethics. Both the CJB and BioéthiqueOnline wll continue to be hosted by the Bioethics Program at the School of Public Health of the Université de Montréal.

Exciting enhancements come with the journal's rebranding:

1. We are proud to annouce the creation of an Advisory Board composed of established international bioethics scholars, who will share their comprehensive and complementary expertise with the Editorial Board. This addition to the $C J B$ structure is an indication that a project that was originally student-led has matured into an initiative that is poised to expand its presence across the Canadian and international bioethics landscapes. We are grateful to the members of the Advisory Board for their support of our vision.

2. Another major innovation is the implementation of a new workflow platform: the Open Journal Systems (Public Knowledge Project). This move will substantially improve the submission process and workflow management. The adoption of the plaftorm is a reflection of the journal's desire to be responsive to the needs expressed by its authors and readership: moving away from an email-based submission system will improve manuscript tracking, and open up new accountability and transparency tools for both contributors and editors.

3. We have also moved to a new publication model: a hybrid form combining Open Issues (manuscripts published on a rolling basis as they are ready) and Special Issues (manuscripts that form a cohesive package and that are published together). Special Issues will be produced in partnership with guest editors and will be an opportunity to focus on an issue that is both timely and that may have received too little attention by our community. This new publication model will allow for the continued timely publication of manuscripts, while opening new opportunities for interdisciplinary collaborations. This first Special Issue inaugrates the new format.

We are proud of this first issue as it is a perfect illustration of the journal's renewed focus. This special issue on Ethics and International Development Research illustrates the tension between working under the auspices of a Canadian institution while conducting research abroad. By offering an opportunity to young researchers supported by a Canadian funding agency, the International Development Research Centre (IDRC), to share their experience conducting research abroad, we seek to meet a number of goals. Most of the cases presented look at research ethics from the perspective of projects that are not exclusively health-focused, a blindspot of much of the research ethics literature. We believe researchers traveling to some of the countries discussed in this issue will find guidance on how to approach local research ethics review. In addition, we hope to introduce the Canadian and international bioethics community to the work of an organisation, the IDRC, of which many might not be aware, despite its rich history and global impact. And at a time where the political pressure to close borders should worry bioethicists worldwide, the choice of a resolutely internationalist issue for the launch of the Canadian Journal of Bioethics is deliberate.

We hope you enjoy this first issue of the new journal, and we look forward to working with you to continue to make this platform a reference for innovative scholarship. So please consider becoming involved, whether as an author, a guest editor, a peer-

Correspondance / Correspondence: Bryn Williams-Jones, bryn.williams-iones@umontreal.ca

ISSN 2561-4665

2018 B Williams-Jones, C Dupras, V Couture, R Boulanger. Creative Commons Attribution 4.0 International License

Les éditeurs suivront les recommandations et les procédures décrites dans le Code The editors follow the recommendations and procedures outlined in the COPE Code of Conduct and Best Practice Guidelines for Journal Editors de COPE. Plus of Conduct and Best Practice Guidelines for Journal Editors. Specifically, the editors précisément, ils travaillent pour s'assurer des plus hautes normes éthiques de la will work to ensure the highest ethical standards of publication, including: the publication, y compris l'identification et la gestion des conflits d'intérêts (pour les identification and management of conflicts of interest (for editors and for authors), the éditeurs et pour les auteurs), la juste évaluation des manuscrits et la publication de fair evaluation of manuscripts, and the publication of manuscripts that meet the manuscrits qui répondent aux normes d'excellence de la revue. journal's standards of excellence. 
reviewer, or a member of the Editorial Board! It is only through your involvement that we can collectively make sure this platform meets our diverse needs as members of the Canadian and international bioethics community.

\section{Lancement de la Revue canadienne de bioéthique}

Après six années (2012-2017) de publication de recherches novatrices dans le domaine de la bioéthique, la revue BioéthiqueOnline devient la Revue canadienne de bioéthique/Canadian Journal of Bioethics (cib-rcb.ca). En tant qu'éditeurs exécutifs de BioéthiqueOnline, nous avons fréquemment entendu des membres de la communauté canadienne de bioéthique parler de la nécessité de développer une plateforme de publication dont l'image refléterait l'étendue et la richesse de nos réflexions collectives, à l'échelle nationale et internationale. Suite à plusieurs discussions avec des collègues à travers le pays au sujet de l'expertise unique développée au cours des dernières années par l'équipe de BioéthiqueOnline, nous avons compris que le nom de notre revue - choisi à l'origine pour refléter son bilinguisme et ses publications en accès libre - ne générait pas l'enthousiasme espéré. II nous est alors apparu pertinent de renommer notre plateforme la Revue canadienne de bioéthique $(\mathrm{RCB})$ et de procéder, du même coup, à quelques améliorations significatives de son fonctionnement.

Notre mission demeure la même : la $R C B$ continuera à offrir un espace bilingue (français et anglais) pour la publication de diverses formes de manuscrits (ex. articles et commentaires évalués par des pairs, éditoriaux, études de cas, travaux créatifs) de haute qualité, stimulant la réflexion et provenant de tous les champs de spécialisation en bioéthique (ex. éthique clinique, éthique de la recherche, éthique et santé publique, éthique du développement des technologies, éthique professionnelle). La revue maintient aussi sa philosophie de publication en accès libre - c'est-à-dire sans aucuns frais de publication pour les auteurs ou frais d'accès pour les lecteurs. Pour ceux qui s'étaient habitués à compter sur BioéthiqueOnline pour rester informés des nouvelles, événements et offres d'emploi liés à la bioéthique, cette ressource demeure en fonction! BioéthiqueOnline sera dorénavant la centrale «médias sociaux» de la revue (Twitter, Facebook, Linkedln). À travers celle-ci, nous continuerons à diffuser des informations récentes et pertinentes pour la bioéthique canadienne. La $R C B$ et BioéthiqueOnline resteront tous

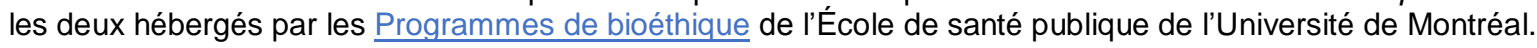

Des améliorations significatives accompagnent la nouvelle image de marque de la revue:

1. Nous sommes fiers d'annoncer la création d'un nouveau Comité consultatif composé de chercheurs canadiens et internationaux reconnus en bioéthique qui partageront leurs expertises diversifiées et complémentaires avec le comité éditorial. Cette nouveauté à la structure de la $R C B$ démontre que l'initiative entreprise et dirigée au départ par des étudiants a grandi pour étendre sa présence au sein de la bioéthique canadienne et à travers le monde. Nous sommes d'ailleurs très reconnaissants envers les membres du Comité consultatif pour leur soutien à la vision promue par cette initiative.

2. Une autre nouveauté importante est la mise en application d'un nouveau système de gestion : l'Open Journal Systems (Public Knowledge Project). Cette nouvelle plateforme aura pour effet de faciliter le processus de soumission et le suivi du travail d'évaluation par les éditeurs et par les pairs. Elle nous permettra de nous éloigner d'un système encombrant de communications par courriel, allégera le suivi des manuscrits en temps réel et nous procurera de nouveaux outils favorisant la responsabilisation des contributeurs et la transparence des procédures.

3. Nous adoptons aussi un nouveau modèle de publication : une approche hybride combinant des numéros ouverts (manuscrits publiés en continu, dès qu'ils sont acceptés et mis en forme) et des numéros spéciaux (recueils de manuscrits publiés simultanément). Les numéros spéciaux seront produits en partenariat avec des éditeurs invités. Ils se concentreront sur une question d'actualité, ayant reçu encore trop peu d'attention de la part de notre communauté. Ce modèle hybride de publication, en plus de permettre la publication des manuscrits en continu, offre de nouvelles opportunités de collaboration interdisciplinaire autour d'un objet d'étude précis. Ce premier numéro spécial inaugure cette nouvelle formule.

Nous sommes fiers de ce numéro inaugural, car il s'agit d'une illustration parfaite de l'approche renouvelée de notre revue. Ce numéro spécial, portant sur l'Éthique et la recherche en développement international, illustre la tension inhérente au travail de chercheurs affiliés à une institution canadienne et conduisant des études à l'étranger. En offrant à de jeunes chercheurs soutenus par un organisme de financement canadien - le Centre de recherches pour le développement international (CRDI) - l'occasion de partager leur expérience de recherche à l'étranger, nous cherchions à atteindre un certain nombre d'objectifs. La plupart des études de cas présentées ici se penchent sur l'éthique de la recherche du point de vue de projets qui ne sont pas exclusivement axés sur la santé, un point faible de nombreuses évaluations en éthique de la recherche. Nous croyons que les chercheurs qui se rendront dans certains pays mentionnés dans ce numéro trouveront des conseils sur la façon d'aborder l'encadrement de l'éthique de la recherche au niveau local. Nous espérons aussi présenter à la communauté canadienne et internationale de bioéthique le travail d'une organisation, le CRDI, dont la riche histoire et l'impact à l'échelle internationale méritent d'être soulignés. À un moment où les pressions politiques pour fermer les frontières devraient inquiéter les bioéthiciens à travers le monde, le choix de produire un numéro résolument internationaliste pour le lancement de la Revue canadienne de bioéthique était délibéré. 
Nous espérons que vous apprécierez ce premier numéro de la nouvelle revue et nous sommes impatients de travailler avec vous pour continuer de faire de cette plateforme une référence en matière de publication de la recherche en bioéthique. N'hésitez pas à vous impliquer, que ce soit en tant qu'auteur, éditeur invité, évaluateur externe ou membre du comité éditorial! C'est grâce à votre implication que nous construirons, collectivement, la $R C B$ qui répondra aux besoins diversifiés que nous éprouvons comme membres de la communauté canadienne et internationale de bioéthique.

\section{Conflit d'intérêts}

Aucun déclaré

\section{Affiliations}

${ }^{1}$ Editor-in-chief/Éditeur en chef

${ }^{2}$ Executive editor/Éditeur executive

Publié/Published: 15 Feb 2018

\section{Conflicts of Interest}

None to declare 